\title{
Environmental Impact and Performance Comparison of Refrigerants (R744 and R134a) in a Mobile Air Conditioning System Used for Cooling Buses
}

\author{
H. G. Ozcana, H. Gunerhanb, A. Hepbaslia, and H. Yaldirakc
}

\begin{abstract}
Environmental awareness and energy efficiency are important concepts in terms of sustainability. Regarding the negative impact on the ozone layer, the largest portion is due to the refrigerants used with a share of $31 \%$ caused by mobile air conditioning (MAC) systems. In this study, refrigerants used in MAC systems were discussed in the terms of environmental aspects. First, the cooling capacity of the bus was calculated by using ASHRAE Handbook and EN 14750 -1 standard for the city of Istanbul in Turkey. Next, a conventional MAC system (with R134a) used for a bus was considered and the performance tests of this system were performed at SAFKAR Inc., located in the city of Izmir, Turkey while the calculations for $R 744$ were made using experimental values of R134a at the same capacity. Finally, various aspects were presented.
\end{abstract}

Index Terms-Alternative refrigerants, carbon dioxide, cooling load, environmental sensitivity, MAC.

\section{INTRODUCTION}

Energy is one of the most important issues in our life. We are warmed in the winter and cooled in the summer while electricity powers most of things. For example, energy is used in a refrigerator for keeping food safe and energy is necessary in oven to cook it. Also amount of energy demand increases continuously. Today, there is a 25 times higher difference occurs when comparing energy consumption worldwide in 1800 . Due to world's population will be around 9 billion people in 2040, energy use worldwide will increase about 35 percent. Environment issues also play an important role when considering living standards and concerns. Common purpose for the world is better environmental standards, such as cleaner air and cleaner water. Also lowering $\mathrm{GHG}$ (i.e., $\mathrm{CO}_{2}$ ) emissions are crucial topics around the world. The tendency of the world has increased in terms of utilization of advanced technologies and decreasing energy demand for providing low $\mathrm{CO}_{2}$ emissions [1].

In 2011 the rates of GHGs were $84 \%, 9 \%, 5 \%$ and $2 \%$ for carbon dioxide, methane, nitrous oxide and fluorinated, respectively. After the Industrial Revolution (began around 1750), activities have caused substantially to climate change by adding $\mathrm{CO}_{2}$ and other GHG gases. Thus, due to increasing

Manuscript received April 14, 2014; revised June 15, 2014.

H. G. Ozcan and A. Hepbasli are with Department of Energy System Engineering, Faculty of Engineering, Yasar University TR-35100 Bornova, Izmir, Turkey (e-mail: \{huseyin.ozcan, arif.hepbasli\}@yasar.edu.tr)

H. Gunerhan is with Department of Mechanical Engineering, Faculty of Engineering, Ege University TR-35100 Bornova, Izmir, Turkey (e-mail: huseyingunerhan@gmail.com).

H. Yaldirak is with SAFKAR Ege Soğutmacilik Inc. TR-35663 Ulukent, Izmir, Turkey (e-mail: hyaldirak@safkar.com). the greenhouse effect, earth's surface temperature has risen. The main sources of the GHGs are electricity, transportation, industry, commercial/residential and agriculture. In 2011 the transportation rate was $28 \%$ in USA and $13 \%$ around the world [2].

The policy of European Union (EU) by 2020 consists of the three main targets, as follows: (i) Reducing GHG levels by $20 \%$, (ii) Increasing the share of renewables to $20 \%$, and (iii) Reducing energy consumption by $20 \%$ [3]. This study contributes to the first and last targets of the EU.

Transportation has to provide comfort parameters and health requirements of the driver and occupants with a proper temperature, humidity values and fresh air amount. Through a cooling system, the rate of accidents and the respiratory illnesses decrease while attentiveness of occupants increases. The factors affecting comfort conditions of the occupants and the driver are temperature and humidity of the air, air motion, odors, dust, lightening, etc. [4]. While calculating the correct cooling load, these factors have to be considered based on EN $14750-1$ and ASHRAE standards.

In the open literature, studies on cooling load have been generally reported for residential applications. In this regard, Aktacir et al., [5] investigated the influence of building thermal insulation on the cooling load. Ghiaus [6] presented a heat balance method for calculating cooling and heating loads of a room. Also there are some studies about cooling load optimization. Assad [7] investigated the cooling load optimization for an irreversible refrigerator while Mohammad et al., [8] studied the same subject using different greenhouse models. In addition, cooling loads for some types of vehicles have been studied. Liu et al., [9] examined ambient conditions and body thermal storage contribution to dynamic cooling load (while vehicle is running) of a train compartment. Solmaz et al., [10] predicted hourly cooling load of a vehicle by considering latitude, longitude, altitude, day of the year, hour of the day, hourly mean ambient air temperature and hourly solar radiation as an input parameters. In a study done by Zheng and Zhu [11], the cooling load of a bus air conditioning unit based on the BP neutral network was calculated in terms of the minimum variance of feed-forward neural net between the true and desired values. Dry bulb temperature, area ratio of window and wall, people density, equipment power, outdoor air criteria, solar radiation, bus's velocity and other ones were specified as input parameters to the cooling load of the bus.

The main objectives of this contribution are to (i) calculate the cooling load of a public bus used in the city of Istanbul, Turkey, (ii) determine the effect of some parameters (e.g., 
occupants, lighting, electrical motors, individual electronic devices) on the cooling load of the bus, and (iii) present a conventional ventilating and air conditioning (VAC) unit and a new generation $\mathrm{VAC}$ unit using $\mathrm{CO}_{2}$ as a refrigerant.

\section{Relations Used in CAlculating the CoOling LoAD OF THE PUBLIC BUS}

The cooling load of a bus consists of internal, infiltration, solar, transmission and fresh air heat gains. Parameters affect the cooling load of the bus (heat gains) are given in Table I.

\begin{tabular}{|c|c|c|c|c|c|}
\hline Parameters & Value & Unit & Parameters & Value & Unit \\
\hline $\begin{array}{l}\text { Speed of the } \\
\text { bus }\end{array}$ & 70 & $\mathrm{~km} / \mathrm{h}$ & $\begin{array}{c}\text { Glass area at } \\
\text { one lateral } \\
\text { side }\end{array}$ & 13 & $\mathrm{~m}^{2}$ \\
\hline $\begin{array}{c}\text { Outside } \\
\text { temperature }\end{array}$ & 35 & ${ }^{\circ} \mathrm{C}$ & $\begin{array}{l}\text { Glass area at } \\
\text { front side }\end{array}$ & 4.5 & $\mathrm{~m}^{2}$ \\
\hline $\begin{array}{l}\text { Outside } \\
\text { relative } \\
\text { humidity }\end{array}$ & $73 \%$ & - & $\begin{array}{l}\text { Glass area at } \\
\text { rear side }\end{array}$ & 1.5 & $\mathrm{~m}^{2}$ \\
\hline $\begin{array}{c}\text { Inside } \\
\text { temperature }\end{array}$ & 25 & ${ }^{\circ} \mathrm{C}$ & $\begin{array}{c}\text { Fresh air rate } \\
\text { per } \\
\text { passenger }\end{array}$ & 12 & $\mathrm{~m}^{3} / \mathrm{h}$ \\
\hline $\begin{array}{l}\text { Inside relative } \\
\text { humidity }\end{array}$ & $55 \%$ & - & $\begin{array}{l}\text { Number of } \\
\text { sited } \\
\text { passenger }\end{array}$ & 31 & - \\
\hline $\begin{array}{l}\text { Outside } \\
\text { absolute } \\
\text { humidity }\end{array}$ & 26.4 & $\mathrm{~g} / \mathrm{kg}$ & $\begin{array}{l}\text { Number of } \\
\text { standing } \\
\text { passengers }\end{array}$ & 66 & - \\
\hline $\begin{array}{c}\text { Inside } \\
\text { absolute } \\
\text { humidity }\end{array}$ & 10.9 & $\mathrm{~g} / \mathrm{kg}$ & $\begin{array}{l}\text { Lightening } \\
\text { heat flux }\end{array}$ & 5 & $\mathrm{~W} / \mathrm{m}^{2}$ \\
\hline $\begin{array}{c}\text { Evaporator } \\
\text { outside } \\
\text { temperature }\end{array}$ & 32 & ${ }^{\circ} \mathrm{C}$ & $\begin{array}{c}\text { Power of } \\
\text { evaporator } \\
\text { fan } \\
\end{array}$ & 1350 & W \\
\hline $\begin{array}{c}\text { Evaporator } \\
\text { outside } \\
\text { absolute } \\
\text { humidity }\end{array}$ & 19.4 & $\mathrm{~g} / \mathrm{kg}$ & $\begin{array}{c}\text { Number of } \\
\text { laptop }\end{array}$ & 10 & - \\
\hline $\begin{array}{c}\text { Length of the } \\
\text { bus }\end{array}$ & 12 & $\mathrm{~m}$ & $\begin{array}{c}\text { Number of } \\
\text { mobile } \\
\text { phone }\end{array}$ & 97 & - \\
\hline $\begin{array}{c}\text { Height of the } \\
\text { bus }\end{array}$ & 2.3 & $\mathrm{~m}$ & $\begin{array}{c}\text { Number of } \\
\text { monitor }\end{array}$ & 2 & \\
\hline $\begin{array}{c}\text { Width of the } \\
\text { bus }\end{array}$ & 2.5 & $\mathrm{~m}$ & $\begin{array}{l}\text { Solar heat } \\
\text { flux }\end{array}$ & 1324 & $\mathrm{~W} / \mathrm{m}^{2}$ \\
\hline Latitude & $40.97 \mathrm{~N}$ & $\circ$ & Declination & 20.4 & $\circ$ \\
\hline
\end{tabular}

The relevant relations used to calculate the cooling load are presented below.

\section{A. Internal Heat Gains}

\section{1) Occupants}

Internal heat gain from occupants varies according to the number of occupants and their activity types, and can be calculated by the following relations [12].

$$
\dot{Q}_{i, o c}=N_{s i t} *\left(\dot{Q}_{s, s i t}+\dot{Q}_{l, s i t}\right)+N_{s \tan d}\left(\dot{Q}_{s, s \tan d}+\dot{Q}_{l, s \tan d}\right)
$$

\section{2) Lightening}

Internal heat gain from lightening varies according to total surface area of lightened surfaces in the inside of the bus and $F l_{u}, F l_{s a}$ factors. It can be obtained from [12].

$$
\dot{Q}_{i, l i g h t}=\dot{q}_{L} * 2[(L * H)+(W i * H)+(L * W i)] F l_{u} * F l_{s a}
$$

\section{3) Electric motors}

Evaporator fan motors are located in the cooled area of the bus. According to their efficiency, some parts of the power input turn into the rotating work and their rest is released as a heat led to the cooling load. The amount of this load is found by [12].

$$
\dot{Q}_{i, e m}=P_{e m} * N_{e m}\left(\frac{1-\eta_{e m}}{\eta_{e m}}\right) F m_{u m} F m_{l m}
$$

\section{4) Individual electronic devices}

There are lots of electronic devices located in the cooled area of a bus (e.g. stations and journey route showing monitors, electronic control unit of a bus, individual electronic devices of occupants such as laptops, tablet PCs, mobile phones, MP3 players and etc.). All of them release heat; so they can be obtained as a cooling load from

$\dot{Q}_{\text {ind }}=N_{\text {lap }} \dot{Q}_{\text {lap }} F l a_{\text {lap }}+N_{\text {com }} \dot{Q}_{\text {com }} F c_{\text {com }}+N_{\text {mon }} \dot{Q}_{\text {mon }}+N_{\text {mob }} \dot{Q}_{\text {mob }}$

\section{B. Infiltration Heat Gain}

The cooling load calculation of the bus is made in the spring and summer seasons under the hot ambient conditions. The indoor air temperatures of the bus are generally $8-10{ }^{\circ} \mathrm{C}$ lower than the outdoor air temperature (being $10^{\circ} \mathrm{C}$ in this study). So, a natural heat movement occurs from outside to inside.

Infiltration occurs due to design failures with time at the external surfaces of the bus (windows, doors, etc.) and the door opening while occupants get on and get off the bus. Infiltration air movement occurs from outside (hotter medium compares with inside), so it handles as a heat gain. It consists of sensible and latent infiltration heat gains based on mass flow rate.

\section{1) Sensible infiltration heat gain}

Sensible infiltration heat gain corresponds to the change of the dry-bulb temperature of the inside air caused by moving airflow from outside due to infiltration and can be calculated using [12],

$$
\dot{Q}_{\mathrm{inf}, s}=C_{s} * Q_{\mathrm{inf}} * \Delta T
$$

\section{2) Latent infiltration heat gain}

Latent infiltration heat gain corresponds to the change of humidity ratio of the inside air caused by airflow movement from outside due to infiltration and can be calculated by [12],

$$
\dot{Q}_{\mathrm{inf}, l}=C_{l} * Q_{\mathrm{inf}} * \Delta W
$$

\section{Solar Heat Gain}

The sun is the most powerful and continuously heat source for the world. Also it affects at any moment as a heat gain during the daytime for the conditioned area of the bus. Solar heat gain consists of direct beam, diffuse and conductive 
components. Their calculation procedure is given below.

\section{1) Direct beam}

The first component of the solar heat gain corresponds to part of solar lights radiated directly from the sun and it can be calculated by the following equations [12].

$$
\begin{gathered}
\dot{Q}_{\text {solar }, d}=A_{d, f} * E_{t, b} * S H G C_{d} I A C_{d} \\
E_{t, b}=E_{b} \cos \theta \\
E_{b}=E_{e x} \exp \left(-\tau_{b} m^{a b}\right) \\
m=1 /\left[\sin \beta+0.50572(6.07995+\beta)^{-1.6364}\right] \\
\beta=90-|L-\delta|, \theta=90-\beta \\
a b=1.219-0.043 \tau_{b}-0.151 \tau_{d}-0.204 \tau_{b} \tau_{d}
\end{gathered}
$$

\section{2) Diffuse}

The second component of the solar heat gain corresponds to the diffuse component. Calculation of this component is more difficult because it has no isotropic nature. Also, its calculation changes with the surface type affecting on it. This component can be calculated by the flowing equations [12].

$$
\begin{gathered}
\dot{Q}_{\text {solar }, \text { dif }}=A_{d i f, f}\left(E_{t, d}+E_{t, r}\right) S H G C_{d i f} I A C_{d i f} \\
E_{s k, d i f}=E_{d i f} Y \\
Y=\max \left(0.45 \text { or } 0.55+0.437 \cos \theta+0.313 \cos ^{2} \theta\right)
\end{gathered}
$$

$$
\begin{gathered}
a d=0.202-0.852 \tau_{b}-0.007 \tau_{d}-0.357 \tau_{b} \tau_{d} \\
E_{d i f}=E_{e x} \exp \left(-\tau_{d} m^{a d}\right) \\
E_{g r, d i f}=\left(E_{b} \sin \beta+E_{d i f}\right) r g \frac{1-\cos \Sigma}{2}
\end{gathered}
$$

\section{Transmission Heat Gain}

Transmission heat gain occurs at six surfaces of the bus via temperature difference between outside and inside medium of the bus. In this section, the transmission heat gain is calculated for only lateral surfaces of the bus.

\section{1) Side walls}

Transmission heat gain consists of three main heat transfer mechanisms through the side walls, namely (i) the convection heat transfer mechanism at the outside and inside of the bus, (ii) the radiation heat transfer mechanism at the outside of the bus, and (iii) the conduction heat transfer mechanism at each external side of the bus. After calculation of these three parameters, the total heat transfer coefficient is determined, and hence the transmission heat gain from side walls can be obtained.

\section{a) Outside convection heat transfer coefficient}

Outside convection heat transfer can be calculated by finding $\operatorname{Re}_{o}, \operatorname{Pr}_{o}, N u_{L, o}$ values, respectively. Before finding $\operatorname{Pr}, N u_{L}$ numbers, the flow type has to be determined [13].

$$
\begin{gathered}
\operatorname{Re}_{o}=\frac{\rho_{o} V_{o} L}{\mu_{o}}>5 \times 105 \text { turbulent flow } \\
N u_{L, o}=0.0337 \operatorname{Re}_{d}^{0.8} \operatorname{Pr}_{o}^{0.33} \\
h_{o}=N u_{L, o} * \frac{k_{o}}{L}
\end{gathered}
$$

\section{b) Inside convection heat transfer coefficient}

The most critical parameter is velocity of air at the inside of the bus while calculating the inside convection heat transfer coefficient. Other calculation steps are the same with obtaining $h_{i}$.

$$
\begin{gathered}
\operatorname{Re}_{i}=\frac{\rho_{i} V_{i} L}{\mu_{i}} \\
N u_{L, i}=0.664 \operatorname{Re}_{i}^{0.5} \operatorname{Pr}_{i}^{0.33} \\
h_{i}=N u_{L, i} * \frac{k_{i}}{L}
\end{gathered}
$$

c) Outside radiation heat transfer coefficient

Outside radiation heat transfer coefficient can be calculated, as given below [14].

$$
h_{r}=\varepsilon \sigma\left(T_{\text {sur }}+T_{\text {surr }}\right)\left(T^{2} \text { sur }+T_{o}^{2}\right)
$$

\section{d) Total heat transfer coefficient}

Besides the convection and radiation heat transfer coefficient values, the conduction coefficient for each material has to be calculated. All of them specify resistance to heat transfer and its inverse gives the total heat transfer coefficient [13].

$$
R_{t, s w}=\frac{1}{h_{o}+h_{r}}+\left(\frac{L_{g a l}}{k_{g a l}}+\frac{L_{p o l}}{k_{p o l}}+\frac{L_{p l y}}{k_{p l y}}\right)+\frac{1}{h_{i}}, U_{t, s w}=\frac{1}{R_{t, s w}}
$$

\section{e) Total heat transfer}

After calculating the total heat transfer coefficient, the amount of the heat transfer can be easily determined by regarding the heat transfer area and the temperature difference between outside and inside mediums.

$$
\dot{Q}_{t, s w}=2\left(U_{t, s w} * A_{t, s w} * \Delta T\right)
$$

\section{2) Transmission heat gains from other surfaces}

In the section, the transmission heat gain from both side walls (lateral surfaces) is calculated. For other four surfaces, the same calculation steps can be followed. Discrepancies occur in values.

\section{3) Conduction heat gain from glass surfaces}

The heat transfer occurs at the glass surfaces not only by direct beam and diffuse radiation, but also by conduction, as calculated below.

$$
\dot{Q}_{c, g s}=A_{g s} * U_{g s}\left(T_{o}-T_{i}\right)
$$




\section{E. Fresh Air Heat Gain}

When considering the travel conditions, one of the most important issues is the quality of the air inside the bus. VAC systems are conditioned inside the bus via the targeted specific temperature and the relative humidity values. But with time, the air quality decreases. So, the fresh air from the outside has to be taken to the inside, passing through fresh and return air filters. This requirement leads to the heat gain at the inside of the bus. It consists of sensible and latent components based on mass flow rate of an air.

\section{1) Sensible fresh air heat gain}

Sensible fresh air heat gain corresponds to the change of the dry-bulb temperature of the indoor air caused by the airflow movement from the outside for increasing the air quality and can be calculated as follows:

$$
\dot{Q}_{f a, s}=C_{s} * Q_{f a} * \Delta T
$$

\section{2) Latent fresh air heat gain}

Latent fresh air heat gain corresponds to the change of the humidity ratio of the inside air caused by the airflow movement from the outside for increasing the air quality and can be obtained by the flowing equation.

$$
\dot{Q}_{f a, l}=C_{s} * Q_{f a} * \Delta W
$$

One can find the heat gain components along their values in $\mathrm{kW}$ in Table II.

TABLE II: HEAT GAIN COMPONENTS

\begin{tabular}{|l|l|l|l|}
\hline Components & Value & Parameters & Value \\
\hline Internal & $\mathbf{1 5 . 9 5}$ & Direct beam & 7.381 \\
\hline Occupants & 12.14 & Diffuse & 3.529 \\
\hline Lightening & 1.337 & Transmission & $\mathbf{1 . 6 6 3}$ \\
\hline Electric motors & 0.133 & Side walls & 0.045 \\
\hline Electronic devices & 2.335 & Other surfaces & 0.059 \\
\hline Infiltration & $\mathbf{2 . 8 1 5}$ & Glass surfaces & 1.6 \\
\hline Sensible & 0.506 & Fresh air & $\mathbf{9 . 5 9 5}$ \\
\hline Latent & 2.309 & Sensible & 2.841 \\
\hline Solar & 10.91 & Latent & 6.754 \\
\hline
\end{tabular}

\section{DATA USED AND ASSUMPTIONS MADE}

The assumptions made in the analysis are listed in Table III.

TABLE III: ASSUMPTIONS MADE

\begin{tabular}{|c|c|c|c|}
\hline$F_{s a}$ & 0.96 & - & $\begin{array}{l}\text { This factor can be less than } 1 \text { for } \\
\text { electronic ballasts }\end{array}$ \\
\hline$P_{e m}$ & 220 & $\mathrm{~W}$ & $\begin{array}{l}\text { standard bus VAC unit per each } \\
\text { motor }\end{array}$ \\
\hline$\eta_{e m}$ & 0.91 & - & $\begin{array}{l}\text { for } 1.35 \mathrm{~kW} \text { evaporator fan } \\
\text { motor }\end{array}$ \\
\hline$F m_{u m}$ & 1 & - & For conventional applications \\
\hline$F m_{l m}$ & 1 & - & For conventional applications \\
\hline$N_{l a p}$ & 10 & - & Occupants work with \\
\hline$\dot{Q}_{\text {lap }}$ & 130 & W & $\begin{array}{l}\text { For } 2.0 \mathrm{GHz} \text { processor, } 2 \mathrm{~GB} \\
\text { RAM, } 430 \mathrm{~mm} \text { screen }\end{array}$ \\
\hline$F_{\text {lap }}$ & 0.25 & - & $\begin{array}{l}\text { Actual power consumption for } \\
\text { laptops is about } 25 \% \text { of } \\
\text { the nameplate values }\end{array}$ \\
\hline$N_{\text {com }}$ & 10 & - & $\begin{array}{l}\text { Bus control unit equals decuple } \\
\text { of desktop computer }\end{array}$ \\
\hline$\dot{Q}_{\text {com }}$ & 1200 & $\mathrm{~W}$ & $2.3 \mathrm{GHz}$ processor, $3 \mathrm{~GB}$ RAM \\
\hline$F c_{c o m}$ & 0.15 & - & $\begin{array}{l}\text { Actual power consumption } \\
\text { is about } 10 \text { to } 15 \% \text { of its } \\
\text { nameplate value. }\end{array}$ \\
\hline$\dot{Q}_{m o n}$ & 28 & $\mathrm{~W}$ & $480 \mathrm{~mm}$ screen \\
\hline$N_{m o n}$ & 2 & - & $\begin{array}{l}\text { There are } 2 \text { stations and journey } \\
\text { route showing monitors }\end{array}$ \\
\hline$N_{m o b}$ & 99 & - & $\begin{array}{l}\text { All of occupants use mobile } \\
\text { phone }\end{array}$ \\
\hline$\dot{Q}_{m o b}$ & 2 & W & Communication at $900 \mathrm{MHz}$ \\
\hline$C_{s}$ & 1.23 & $\begin{array}{l}\mathrm{W} / \\
(\mathrm{L} \cdot \mathrm{s} \cdot \mathrm{K} \\
\end{array}$ & $\begin{array}{l}\text { Like as many HVAC } \\
\text { applications }\end{array}$ \\
\hline$\dot{Q}_{\text {inf }}$ & 178.2 & $\mathrm{~m}^{3} / \mathrm{h}$ & $15 \%$ of the fresh air rate \\
\hline$\Delta T$ & 10 & ${ }^{\circ} \mathrm{C}$ & $\begin{array}{l}\text { Outside air temperature is taken } \\
35^{\circ} \mathrm{C} \text { for the city of Istanbul } \\
\text { (zone } 2 \text { ) and inside air } \\
\text { temperature is taken } 25^{\circ} \mathrm{C} \text { for } \\
\text { category B vehicles }\end{array}$ \\
\hline$C_{l}$ & 3010 & $\begin{array}{l}\mathrm{W} / \\
(\mathrm{L} / \mathrm{s})\end{array}$ & $\begin{array}{l}\text { Like as many HVAC } \\
\text { applications }\end{array}$ \\
\hline$\Delta W$ & 15.5 & $\mathrm{~g} / \mathrm{kg}$ & $\begin{array}{l}\text { Outside air specific humidity is } \\
\text { found under } 35^{\circ} \mathrm{C} \text { and } 73 \% \\
\text { relative humidity conditions for } \\
\text { the city of Istanbul and inside } \\
\text { air specific humidity is obtained } \\
\text { under } 25^{\circ} \mathrm{C} \text { and } 55 \% \text { relative } \\
\text { humidity conditions with } 30 \mathrm{~m} \\
\text { elevation [15] }\end{array}$ \\
\hline$A_{d, f}$ & 13 & $\mathrm{~m}^{2}$ & $\begin{array}{l}\text { One lateral side fenestration } \\
\text { area of the bus }\end{array}$ \\
\hline$L$ & 40.97 & ${ }^{\circ} \mathrm{N}$ & for the city of Istanbul \\
\hline$\delta$ & 23.4 & $\circ$ & for the 21st day of June \\
\hline$E_{o}$ & 1323 & $\mathrm{~W} / \mathrm{m}^{2}$ & for the 21 st day of June \\
\hline$\tau_{b}$ & 0.505 & - & for the 21 st day of June \\
\hline$\tau_{d}$ & 1.892 & - & for the 21 st day of June \\
\hline$S H G C_{d}$ & 0.814 & - & $\begin{array}{l}6 \mathrm{~mm} \text { thickness, uncoated } \\
\text { single glazing }\end{array}$ \\
\hline$I A C_{d}$ & 1 & - & No inside shading device \\
\hline$r_{g}$ & 0.2 & - & $\begin{array}{l}\text { Typical mixture of ground } \\
\text { surfaces }\end{array}$ \\
\hline$\sum$ & 90 & $\circ$ & $\begin{array}{l}\text { Diffuse solar radiation effects } \\
\text { vertical to the external } \\
\text { fenestration surfaces of the bus }\end{array}$ \\
\hline$S H G C_{d i f}$ & 0.73 & - & $\begin{array}{l}6 \mathrm{~mm} \text { thickness, uncoated } \\
\text { single glazing }\end{array}$ \\
\hline$I A C_{d i f}$ & 1 & - & no inside shading device \\
\hline$\mu_{o}$ & 0.0000188 & $\begin{array}{l}\mathrm{Ns} / \\
\mathrm{m}^{2}\end{array}$ & $\begin{array}{l}35^{\circ} \mathrm{C} \text { air temperature and fully } \\
\text { turbulent external flow }\end{array}$ \\
\hline
\end{tabular}

\begin{tabular}{|l|l|l|l|}
\hline Item & Value & Unit & Remarks \\
\hline$\dot{Q}_{s, s i t}$ & 70 & $\mathrm{~kW}$ & $\begin{array}{l}\text { Seated, very light work (degree } \\
\text { of activity) in offices, hotels, } \\
\text { apartments }\end{array}$ \\
\hline$\dot{Q}_{l, s i t}$ & 45 & $\mathrm{~kW}$ & $\begin{array}{l}\text { Seated, very light work (degree } \\
\text { of activity) in offices, hotels, } \\
\text { apartments }\end{array}$ \\
\hline$\dot{Q}_{s, s \tan d}$ & 75 & $\mathrm{~kW}$ & $\begin{array}{l}\text { Standing, light work (degree of } \\
\text { activity) in department store; } \\
\text { retail store walking }\end{array}$ \\
\hline$\dot{Q}_{l, s \tan d}$ & 55 & $\mathrm{~kW}$ & $\begin{array}{l}\text { Standing, light work (degree of } \\
\text { activity) in department store; } \\
\text { retail store walking }\end{array}$ \\
\hline$\dot{q}_{L}$ & 11 & $\mathrm{~W} / \mathrm{m}^{2}$ & $\begin{array}{l}\text { transportation lighting power } \\
\text { densities }\end{array}$ \\
\hline$F_{u}$ & 1 & - & Commercial applications \\
\hline
\end{tabular}




\begin{tabular}{|l|l|l|l|}
\hline$\rho_{o}$ & 1.134 & $\begin{array}{l}\mathrm{kg} / \\
\mathrm{m}^{3}\end{array}$ & $\begin{array}{l}35^{\circ} \mathrm{C} \text { air temperature and fully } \\
\text { turbulent external flow }\end{array}$ \\
\hline$P r_{o}$ & 0.705 & - & $\begin{array}{l}35^{\circ} \mathrm{C} \text { air temperature and fully } \\
\text { turbulent external flow }\end{array}$ \\
\hline$\mu_{i}$ & $\begin{array}{l}0.0000184 \\
6\end{array}$ & $\begin{array}{l}\mathrm{Ns} / \\
\mathrm{m}^{2}\end{array}$ & $\begin{array}{l}25^{\circ} \mathrm{C} \text { air temperature and } \\
\text { combined external flow }\end{array}$ \\
\hline$\rho_{i}$ & 1.16 & $\begin{array}{l}\mathrm{kg} / \\
\mathrm{m}^{3}\end{array}$ & $\begin{array}{l}25^{\circ} \mathrm{C} \text { air temperature and } \\
\text { combined external flow }\end{array}$ \\
\hline $\operatorname{Pr}_{i}$ & 0.707 & - & $\begin{array}{l}25^{\circ} \mathrm{C} \text { air temperature and } \\
\text { combined external flow }\end{array}$ \\
\hline $\mathcal{E}$ & 0.7 & - & Isolated rural site \\
\hline$\sigma$ & $5.67 * 10^{-8}$ & $\begin{array}{l}\mathrm{W} / \\
\mathrm{m}^{2} \mathrm{~K}^{4}\end{array}$ & - \\
\hline$L_{g a l}$ & 0.01 & $\mathrm{~m}$ & Galvanized sheet \\
\hline$L_{p o l}$ & 0.04 & $\mathrm{~m}$ & Polystyrene foam \\
\hline$L_{p l y}$ & 0.004 & $\mathrm{~m}^{\prime}$ & Plywood \\
\hline$k_{g a l}$ & 0.00046 & $\begin{array}{l}\mathrm{W} / \\
\mathrm{m}^{2} \mathrm{~K}\end{array}$ & Galvanized sheet \\
\hline$k_{p o l}$ & 0.0011 & $\begin{array}{l}\mathrm{W} / \\
\mathrm{m}^{2} \mathrm{~K}\end{array}$ & Polystyrene foam \\
\hline$k_{p l y}$ & 0.00015 & $\begin{array}{l}\mathrm{W} / \\
\mathrm{m}^{2} \mathrm{~K}\end{array}$ & Plywood \\
\hline$U_{g s}$ & 5 & $\begin{array}{l}\mathrm{W} / \mathrm{m}^{2} \cdot \\
\mathrm{K}\end{array}$ & 6.4 mm acrylic single glazing \\
\hline
\end{tabular}

\section{SYSTEM DESCRIPTIONS}

\section{A. Conventional VAC system}

Conventional VAC system that using $\mathrm{R} 134 \mathrm{a}$ as a refrigerant has a capacity which corresponds to the heat gain calculation of the bus, as shown in Fig. 1. The basic components of the VAC system are numbered between 1 to 9 The working principle of the VAC system is based on the refrigerant's cycle between the numbered components continuously. When the engine of the bus begins to work, an open type compressor of the VAC system is derived via belt and pulley mechanism. So, the refrigerant is compressed from a low pressure to a high pressure. After this compression process, the superheated refrigerant flows through the condenser coils by passing the copper tubes. In the condenser coils, the superheated refrigerant changes its phase to its liquid form. It can be achieved by rejecting heat to outside. The rejected heat is transferred to the ambient air by axial condenser fans, as shown in Fig. 1. Then, the refrigerant flows to the external pressure equalized expansion valve. A liquid tank and a drier are used in the VAC system before the expansion valve. The liquid tank can separate the gas and liquid phases of the refrigerant. So, the refrigerant can flow into the expansion valve totally at a liquid phase. This component has to be used in the cycle because at the end of the condenser coil the phase of the refrigerant cannot always be in the only liquid form. The refrigerant flows through the evaporator coils in the mixture phase and evaporates. It can be achieved by absorbing the heat from inside. Absorbing heat is transferred to the conditioned air by blower evaporator fans. This air is taken from inside the bus and then given into the bus. At the end of this process, the refrigerant turns into initial state and thus the cycle is completed.

Another important two concepts for the cycle safety are sub cooling and superheating. The sub cooling is designed after the condenser coils for getting the refrigerant into the expansion valve totally at the liquid phase and the superheating is designed after the evaporator coils for getting the refrigerant into the compressor totally at the vapor phase [16].

The working parameters of the VAC system is determined by carrying out a performance test at SAFKAR INC. After this test, the temperature-entropy and pressure enthalpy graphics are plotted, as shown Fig. 2 and Fig. 3, respectively [17].

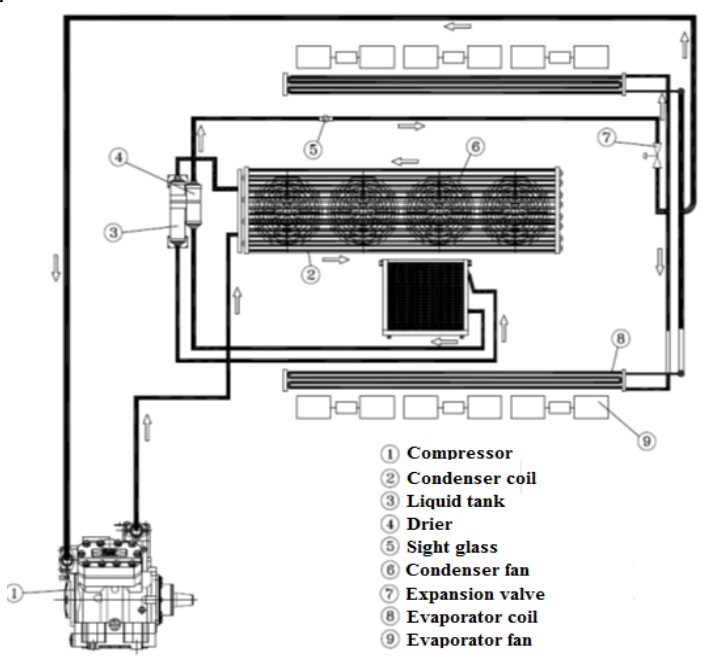

Fig. 1. Conventional VAC system refrigerant flow [16].

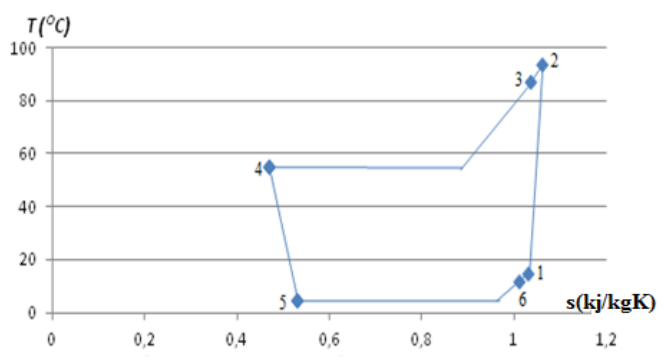

Fig. 2. Temperature entropy graphic.

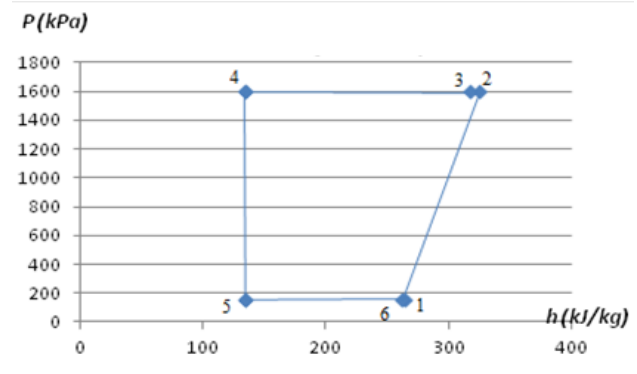

Fig. 3. Pressure enthalpy graphic.

\section{B. R744 VAC System}

All types of cooling devices are designed based on the heat gain calculation. The evaporator coil is then designed to meet the required load. Also, the capacities of the evaporator fans are determined. The evaporation and condensation temperatures are specified for selecting a compressor. The capacity of the condenser coil and the power of the condenser fans can be calculated by using the calculated evaporator coil and compressor capacities. An expansion valve can be selected. So, the basic components can be calculated and selected. In this section the same steps are derived for designing the VAC system using carbon dioxide (R744) as a refrigerant. 


\section{1) Specifying operating conditions}

In the open literature, studies on operating conditions of R744 VAC systems are handled between 30 - 45 bars for low pressures and 90-120 bars for high pressures. In these intervals, an optimization will be done for specifying both low and high pressures. As regards to the evaporation and condensation temperatures, they are handled $7.5^{\circ} \mathrm{C}$ and $50^{\circ} \mathrm{C}$, respectively based on a temperature difference of $15^{\circ} \mathrm{C}$. For specifying the condensation temperature, the temperature of outside ambient is taken into account, being $35^{\circ} \mathrm{C}$ for the city of İstanbul. Thus, the condensation temperature can be calculated as $35^{\circ} \mathrm{C}+\Delta \mathrm{T}\left(15^{\circ} \mathrm{C}\right)=50^{\circ} \mathrm{C}$. The similar approach can be applied for specifying the evaporation temperature. The most comfortable temperature and relative humidity values are determined as $23^{\circ} \mathrm{C}$ and $55 \%$, respectively [18]. Thus, the evaporation temperature can be calculated as $23^{\circ} \mathrm{C}-\Delta \mathrm{T}\left(15^{\circ} \mathrm{C}\right)=8^{\circ} \mathrm{C}$. Considering that the technical specification of the compressors and the expansion valves, the evaporation temperature values are given from $-10^{\circ} \mathrm{C}$, to $10^{\circ} \mathrm{C}$ with an interval of $2.5^{\circ} \mathrm{C}$. For the R744 VAC system, the evaporation temperature is determined to be $7.5^{\circ} \mathrm{C}$.

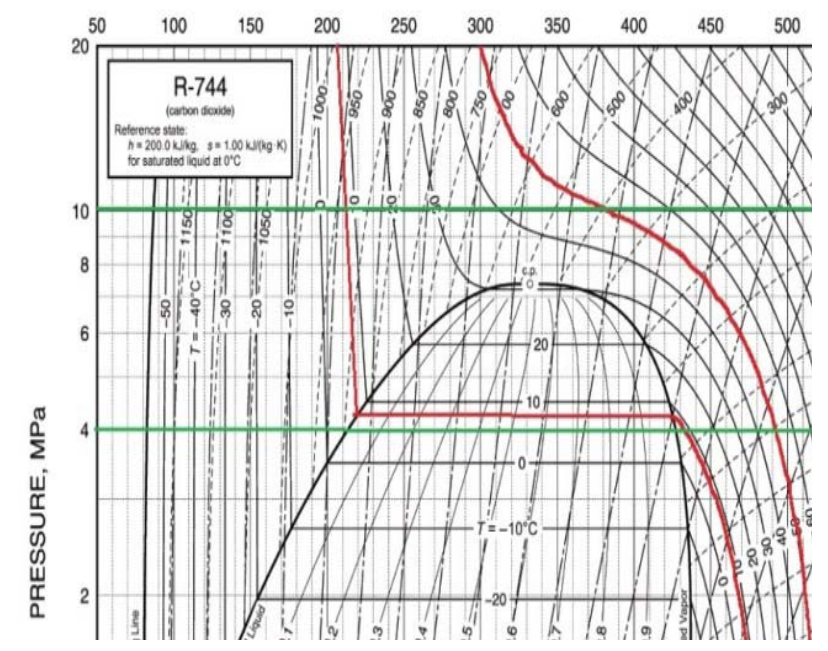

Fig. 4. Working range of R744 VAC system.

For specifying the high and low pressures of the R744 VAC system, the gas cooler exit pressure, which effects the COP value of the cycle, is used, corresponding to the high pressure of the R744 VAC system [19]. The preliminary design is performed after reviewing the open literature and the gas cooler exit pressure values, as shown in Fig. 4. From the figure, the evaporation pressure that corresponds to an evaporation temperature can be found 42.298 bars by interpolation. Also, the optimum high pressure is 108 bars when the outside ambient temperature is $35{ }^{\circ} \mathrm{C}$, the compressor efficiency is 0.75 and the evaporation temperature is $7^{\circ} \mathrm{C}[18]$. As a result, the operating conditions are specified.

\section{CAlculation of Main Components}

Heat gain calculation is given in Section II. The results of this calculation led to specifying the capacity of the evaporator heat exchanger. While the evaporator heat exchanger capacity is calculated, the Colburn factor, the density and the specific heat of the air at an average temperature, a volumetric flow rate of the air, a conduction heat transfer coefficient of coil, etc. are considered [20].

Then, the evaporator fan calculation is carried out. Main function of the evaporator fan is to recirculate the air passing through the evaporator coils that leads to the air to cool because the refrigerant absorbs the heat while evaporating. While calculating the evaporator fan capacity required, the volumetric flow rate and the power consumption are assumed. The volumetric flow rate is calculated. In conclusion, a comparison has to be done with volumetric flow rates of two conditions (the temperature difference and fresh air).

After that, the compressor capacity is calculated considering the evaporation temperature, the condensation temperature and the cooling capacity of the VAC unit. Under these calculations, there is no mass production for the open type compressor, of which usage is dominant in the bus VAC units. Instead of this type of the compressor, hermetic models can be obtained.

Thereafter, the gas cooler heat exchanger capacity is calculated while the Colburn factor, the density and specific heat of the air at an average temperature, the volumetric flow rate of the air, the conduction heat transfer coefficient of the coil, etc. are considered [20]. For the gas cooler fan, only the calculation temperature difference is taken into account. The main function of the condenser fan is to reject the air passing through the condenser coils that leads to the air to warm because the refrigerant rejects the heat while condensing.

In the R744 VAC system, the gas cooler is placed instead of the condenser used in conventional VAC systems. So, the pressure at the exit of the gas cooler is still high. There is a need for another component that decreases the pressure level and makes the suitable expansion valve usage possible. Simultaneously, it provides a superheating for the cycle. This component is called internal heat exchanger and its capacity can be calculated with specifying the exit temperature of the refrigerant from this device (the exit temperature of the gas cooler and the mass flow rate of the refrigerant have been already calculated). When the exit temperature of the internal heat exchanger is assumed to be equal the ambient air temperature, the COP value of the R744 VAC system reaches its maximum value $\left(35^{\circ} \mathrm{C}\right.$ in this study) [18].

One of the basic differences between the conventional and R744 VAC systems are due to the expansion valve usage. As described before, the refrigerant phase has to be $100 \%$ liquid at the conventional expansion valve. On the other hand, the refrigerant phase can be liquid and the vapor mixture (the refrigerant cannot be totally condensed because of the high pressure value) at the expansion valve for the R744 VAC system. This working condition can be provided by an electronic expansion valve with a step motor actuator.

\section{A. Specifying Working Parameters of the R744 VAC System}

Basic components of the new generation R744 VAC system of the bus are numbered between 1 to 6 in Fig. 5. The working principle of the R744 VAC system based on the refrigerant's cycle between the numbered components is almost similar to the conventional one. One of the differences 
for this VAC unit is having an internal heat exchanger in the cooling cycle that provides the refrigerant to approach to its saturated liquid line and superheat the refrigerant before entering the compressor. Another difference occurs due to the expansion valve because the refrigerant phase can be liquid and vapor for this cycle. Also, the accumulator is used for keeping non-evaporated refrigerant before the compressor.

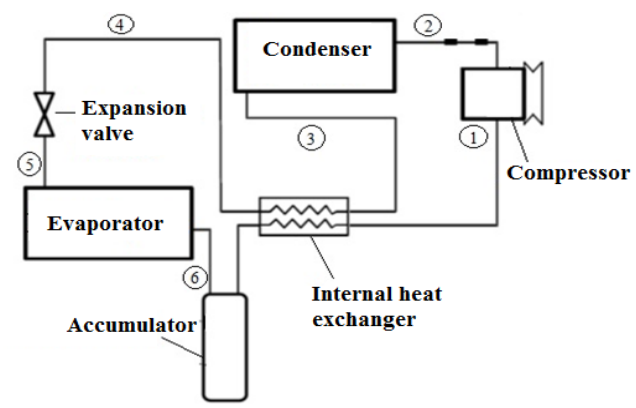

Fig. 5. R744 VAC System Refrigerant flow [21].

Under these calculations, the temperature-entropy and pressure - enthalpy graphics are plotted as shown in Fig. 6 and Fig. 7, respectively.

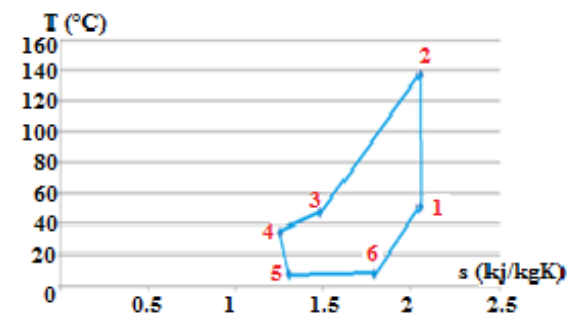

Fig. 6. Temperature Entropy Graphic of R744 VAC System.

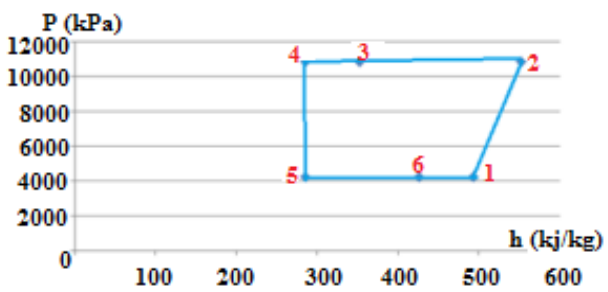

Fig. 7. Pressure Enthalpy Graphic of R744 VAC System.

\section{CONCLUSIONS}

Only the refrigerants with a GWP value lower than 150 will be used based on the EU directives. R744 is one of the refrigerant solution provides that requirement. By this refrigerant usage, the following advantages may be listed.

1) Compared to R134a, the GWP value is 1300 times lower.

2) When comparing the cost of the refrigerant with R134a, R744 is 18 times cheaper ( $0.52 €$ to $9.38 €$ per kilogram).

3) Compared to R134a, the volumetric heat capacity (energy density absorbing by unit volume) is 8.4 times higher.

4) When comparing to R134a, the evaporation latent heat value is 2.65 times higher. It leads to the lower amount of the refrigerant usage for R744 at the same capacity (less friction losses).

5) Although the compressor works at a high pressure, the pressure ratio is lower for R744 cycle. So, the compressors are more efficient (better COP values at the same cooling capacity).

6) The pull down load overcomes faster.

7) The COP values get lower than the R134a VAC system at high temperatures (mostly higher than 35 ).

On the other hand, there are some disadvantages occur when using R744. The cycle operates at high pressure values (108 bars at high pressure side). So, the components have to meet these high pressure values. This means that a heavier VAC unit leads to increasing the indirect emissions. Also, the initial investment cost is almost three times higher for R744 VAC systems.

\section{APPENDIX}

\section{Nomenclature:}

$q$

A

$a b$

ad

C

E

$F c$

$F_{1}$

Fla

Fm

$h$

$H$

$k$

$L$

$L$ heat rate, $\mathrm{kW}$

heat flux, $\mathrm{kW} / \mathrm{m}^{2}$

area, $\mathrm{m}^{2}$

beam air mass exponents, dimensionless

diffuse air mass exponents, dimensionless

air heat factor, $\mathrm{W} /(\mathrm{LK} / \mathrm{s})$

irradiance, $\mathrm{W} / \mathrm{m}^{2}$

safety factor of computer, dimensionless

lightening factor, dimensionless

safety factor of laptop, dimensionless

motor factor, dimensionless

heat transfer coefficient, $\mathrm{kW} / \mathrm{m}^{2} \mathrm{~K}$

height of the bus, $\mathrm{m}$

conduction heat transfer coefficient, $\mathrm{kW} / \mathrm{m}^{2} \mathrm{~K}$

latitude, ${ }^{\circ}$

length of the bus, $m$

air mass, dimensionless

number of, dimensionless

Nusselt number, dimensionless

power of evaporator fans, W

Prandtl number, dimensionless

volumetric flow rate, $\mathrm{m}^{3} / \mathrm{s}$

reflectance, dimensionless

Reynolds number, dimensionless

temperature, $K$

total heat transfer coefficient, $\mathrm{kW} / \mathrm{m} 2 \mathrm{~K}$

velocity, $\mathrm{m} / \mathrm{s}$

specific humidity, $\mathrm{g} / \mathrm{kg}$

width of the bus, $m$

solar altitude angle, ${ }^{\circ}$

decleration, ${ }^{\circ}$

angle of incidence, ${ }^{\circ}$

indoor solar attenuation coefficient, dimensionless solar heat gain coefficient, dimensionless total heat transfer resistance, $\mathrm{m}^{2} \mathrm{~K} / \mathrm{kW}$

slope of the surface, ${ }^{\circ}$

\section{Superscripts \\ b beam \\ c conduction \\ c convection \\ com computer \\ d direct beam \\ dif diffuse \\ ed electronic devices \\ em electric motor \\ ex extraterrestrial \\ $f \quad$ fenestration \\ $f a \quad$ fresh air}




$\begin{array}{ll}g & \text { ground } \\ g a_{1} & \text { galvanized sheet } \\ g r & \text { ground reflected } \\ g s & \text { glass surface } \\ i & \text { inside } \\ i & \text { internal } \\ \text { inf } & \text { infiltration } \\ 1 & \text { latent } \\ \text { lap } & \text { laptop } \\ \text { light } & \text { lightening } \\ \text { lm } & \text { load factor } \\ \text { mob } & \text { mobile phone } \\ \text { mon } & \text { monitor } \\ o & \text { outside } \\ o c & \text { occupants } \\ \text { ply } & \text { plywood } \\ \text { pol } & \text { polystyrene foam } \\ r & \text { radiation } \\ s & \text { sensible } \\ \text { sa } & \text { special allowance } \\ \text { sit } & \text { sitting } \\ s k & \text { sky } \\ \text { solar } & \text { solar radiation } \\ \text { stand } & \text { standing } \\ \text { sur } & \text { surface } \\ \text { surr } & \text { surrounding } \\ \text { sw } & \text { sidewall } \\ t & \text { transmission } \\ u & \text { use } \\ \text { um } & \text { use factor } \\ & \end{array}$

\section{Greek letters:}

$\begin{array}{ll}\Delta & \text { difference } \\ \eta & \text { efficiency of evaporator fans, dimensionless } \\ \tau & \text { optical depth, dimensionless } \\ \mu & \text { dynamic viscosity, Ns } / \mathrm{m}^{2} \\ \rho & \text { density, } \mathrm{kg} / \mathrm{m}^{3} \\ \varepsilon & \text { emissivity, dimensionless } \\ \sigma & \text { Stefan Boltzmann constant, } 5.67^{*} 10^{-8} \mathrm{~W} / \mathrm{m}^{2} \mathrm{~K}^{4}\end{array}$

\section{Over dot: quantity per time}

\section{REFERENCES}

[1] The Outlook for Energy: A View to 2040, Exxon Mobil Corporation, Irving, Texas, pp. 75039-2298, 2014.

[2] Greenhouse Gas Emissions Data. [Online]. Available: http://www.epa.gov/climatechange.

[3] EFinal $\quad$ Version. [Online]. Available: http://www.roadmap2050.eu/attachments/files/EnergySavings2020-F ullReport.pdf.

[4] Thermal Comfort Standards. [Online]. Available: http://courses.washington.edu/me333afe/Comfort_Health.pdf.

[5] M. A. Aktacir, O. Buyukalaca, and T. Yilmaz, "A case study for influence of building thermal insulation on cooling load and air-conditioning system in the hot and humid regions," Applied Energy, vol. 87, pp. 599-607, 2010.

[6] C. Ghiaus. Causality Issue in the Heat Balance Method for Calculating the Design Heating and Cooling Load. [Online]. Available: http://www.sciencedirect.com/science/article/pii/S036054421200786.

[7] M. E. H. Assad, "Cooling load optimization of an irreversible refrigerator with combined heat transfer," International Journal of Energy and Environment, vol. 4, no. 3, pp. 377-386, 2013.

[8] A. T. Mohammad, S. B. Mat, M. S. Alrubaih, and A. A. A. Abidi, "Optimization of cooling load for different greenhouse models in Malaysia," International Journal of Renewable Energy Research, vol. 4, no. 1, 2014.

[9] W. Liu, Q. Deng, W. Huang, and R. Liu, "Variation in cooling load of a moving air-conditioned train compartment under the effects of ambient conditions and body thermal storage," Applied Thermal Engineering, vol. 31, pp. 1150-1162, 2011.

[10] O. Solmaz, M. Ozgoren, and M. H. Aksoy, "Hourly cooling load prediction of a vehicle in the southern region of Turkey by Artificial
Neural Network," Energy Conversion and Management, vol. 82, pp. 177-187, 2014.

[11] H. Zheng and C. Zhu, "Application research of cooling load of bus air conditioning based on BP neutral network," in Proc. the 2008 International Seminar on Future Information Technology and Management Engineering, 2008.

[12] ASHRAE Handbook-Fundamentals (SI), Ashrae Handbook Series, 2009.

[13] Y.A. Cengel, Heat and Mass Transfer, Third Edition, Mc-Graw Hill Education, 2006.

[14] P. F. Incropera, P. D. Dewitt, T. L. Bergman, and A. S. Lavine, Fundamentals of Heat and Mass Transfer, Sixth Edition, John Wiley and Sons, 2006.

[15] Psychometric Diagram Viewer Program Version 1.0.6., Daikin Europe, Zandvoordestraat, 300 B8400 Oostende.

[16] T. Uslu, Presentation on Vehicle Air Conditioning, Safkar Inc., Izmir, Turkey, 2012 (in Turkish).

[17] Technical Specification of ES 438W Bus Air Conditioning Device.pdf, Safkar Inc., İzmir, 2011.

[18] A. A. Chowdhury, M. G. Khan, and M. M. K. Resul, "Thermal comfort analysis and simulation for various low-energy cooling-technologies applied to an office building in a subtropical climate," Applied Energy, vol. 85 , no. 6 , pp. 449-462, 2008.

[19] A. Rozhentsev and C. Wang, "Some design features of a $\mathrm{CO}_{2}$ air conditioner," Applied Thermal Engineering, vol. 21, pp. 871-880, 2001.

[20] N. Kayansayan, "Heat transfer characterization of plate fin-tube heat exchangers," International Journal of Refrigeration, vol. 17, no. 1, 1994.

[21] H. G. Ozcan, "Using a natural refrigerant carbon dioxide instead of synthetic refrigerant R134a in mobile air conditioning system which provides cooling inside of the bus," MSc. thesis, Dept. Mechanical Eng., Ege University, İzmir, Turkey, 2012.

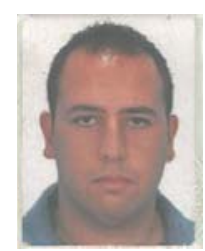

H. G. Ozcan was born in Bodrum, Turkey on March 21, 1985. He received his B.S. in mechanical engineering from Dokuz Eylul University (DEU), Turkey in 2009 and $\mathrm{He}$ received his bachelor's degree diploma from Anadolu University (AU), Turkey in 2012, He received his bachelor's M.S. from Ege University, Turkey in 2013 while he was working in industry. Also he has been studying a Ph.D. in mechanical engineering at Ege University since 2013 February.

He worked as a railway systems engineer at Research and Development Department at SAFKAR Inc. for 3 years. His main responsibility subjects are (i) thermal load calculation of HVAC systems, (ii) capacity calculations of main components, (iii) government supported projects, (iv) permanently research about railway and (v) HVAC standards and making product trees and cost analysis. Than he has been appointed as a research assistant in Energy Systems Engineering Department at Yaşar University in Izmir, Turkey since October 2013. His main responsibility subjects are (i) assist to the lectures (responsible for application of lectures), (ii) researches about clean energy technologies and HVAC - R, (iii) technical plant visits and (iv) working for writing an SCI article.

MSc. Engineer Ozcan is a member of Union of Chambers of Turkish Engineers and Architects (UCTEA).

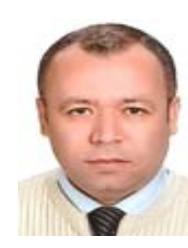

H. Gunerhan was born in Izmir, Turkey in 1966. He received his B.S. in mechanical engineering Department from Dokuz Eylul University, Turkey in 1990, he received his M.S. from Solar Energy Institute, Ege University of Izmir, Turkey in 1992 and a Ph.D. in solar energy from Solar Energy Institute, Ege University in 1999.

He completed his military service in 2000 . He worked as a research assistant in solar energy institute of Ege University from 1991 to 2001. He was vice director of Ege University Center for Environmental Studies between 2004-2010. He worked as a researcher for 3 months in 2013 at the Dalhousie University, Canada. He has been worked at the Mechanical Engineering Department, Ege University in Izmir, Turkey since 2001.

Dr. Gunerhan is the author and co-author of over 30 papers in a national and international journals. His research has been involved with energy and exergy analyses and assessments of energy-related systems, renewable energy sources, ground-source heat pumps, and sustainable energy technologies. He is an associate professor in department of thermodynamics. 


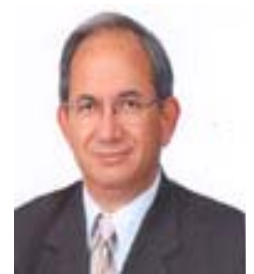

A. Hepbasli was born in Izmir, Turkey on June 27, 1958. He received B.S. (first class honor) in mechanicalengineering from Selcuk University (SU), Turkey in 1980, M.S. from Istanbul Technical University of Istanbul, Turkey in 1985 and a Ph.D. in mechanical engineering from Selcuk University in 1990 while he was working in industry. He joined Ege University in 1996 after about a ten-year period in industry at different positions and a one-year period at Izmir Branch Office of Chamber of Mechanical Engineers as a consultant. He has been appointed as the head of Energy Systems Engineering Department at Yaşar University in Izmir, Turkey since September 2012. He is the author and co-author of over 530 papers (over 250 SCI-based papers with an h-index of 34) on a national and international basis as well as several national and international books and book chapters. His research has been involved with energy, exergy, exergoeconomic and exergoenvironmental analyses and assessments of energy-related systems, energy/exergy efficiency and management, clean energy technologies, ground-source heat pumps, utilization and potential of renewable energy sources and sustainable energy technologies.
He has served as a consultant for industry in cases involving his research area and is also a member in the international advisory board of eight prestigious energy-related journals, and an associate editor of Journal of Energy Engineering (ASCE) while also serving many energy journals and industrial projects as a reviewer.

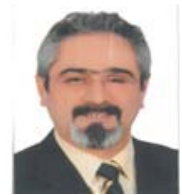

H. Yaldirak was born in Germany in 1966 . He received his B.S. in mechanical engineering Department from Dokuz Eylul University, Turkey in 1990. He completed his military service in 1995. He has been working at SAFKAR Inc. since 1992. He began as a product engineer and now he is a research and development director.

Mr. Yaldirak is a member of Union of Chambers of Turkish Engineers and Architects (UCTEA). 